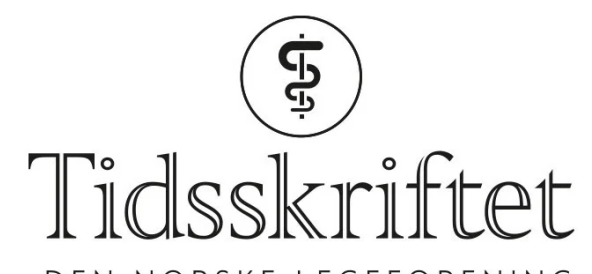

DEN NORSKE LEGEFORENING

\title{
For godt til å være sant
}

KOMMENTAR

\section{JENS IVAR BROX}

Jens Ivar Brox (f. 1955) er overlege ved ryggseksjonen ved Ortopedisk avdeling ved Oslo universitetssykehus, Rikshospitalet.

Oppgitte interessekonflikter: Forfatteren har mottatt et mindre engangshonorar fra Orthomedic for forelesning for ryggortopeder.

Email: jens.ivar.brox@rikshospitalet.no

Ryggseksjonen

Ortopedisk avdeling

Oslo universitetssykehus, Rikshospitalet

Overvurdering av effekt, manglende rapportering av komplikasjoner og finansielle transaksjoner er avdekket i det som beskrives som den største skandalen i amerikansk ryggmedisin gjennom tidene. 


\section{THE}

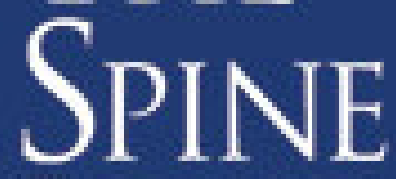

IOURNAL

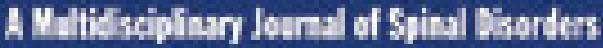
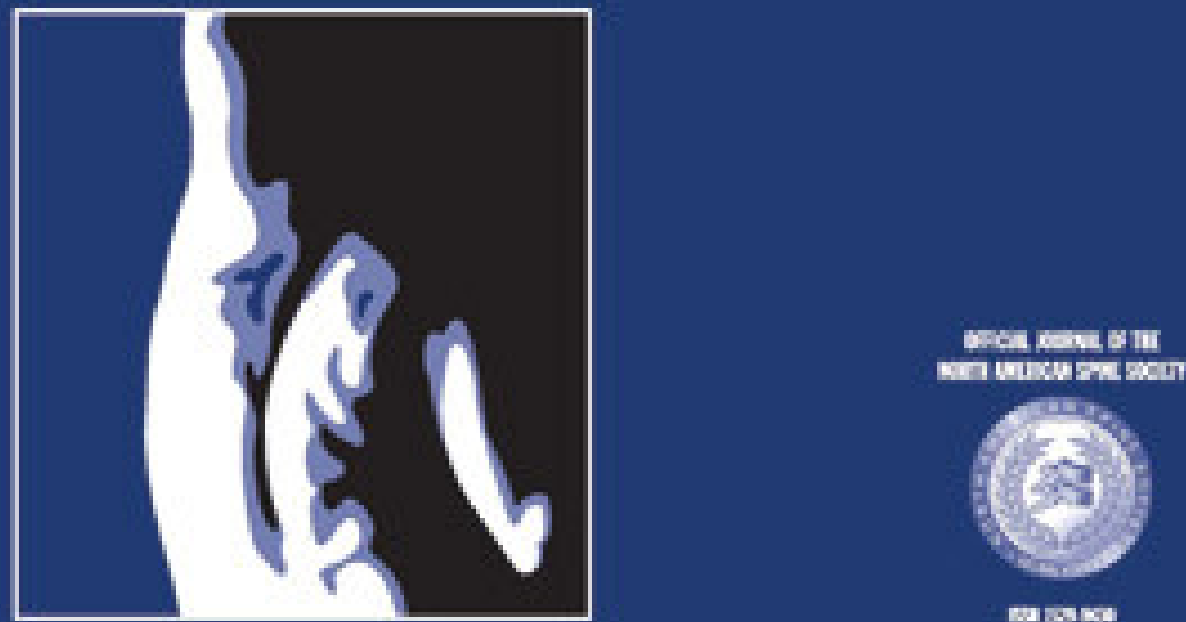

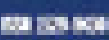

Faksimile av Spine Journal

"Yes, isn't it pretty to think so,» skrev Ernest Hemingway i The Sun Also Rises.

Det er grunn til å gi honnør til Eugene Carragee, professor i ryggkirurgi ved Stanford University og redaktør av Spine Journal, og hans medforfattere. I en systematisk oversiktartikkel har de kritisk vurdert sikkerhetsprofilen til det beinvekststimulerende preparatet rhBMP-2 (recombinant human bone morphogenic protein-2 (1) over tid, fra de første industrisponsede studiene til senere uavhengige vurderinger av produktet, samt ved en uavhengig gjennomgang av offentlig tilgjengelige forskningsdata. De fant en oppsiktsvekkende mangel på rapportering av komplikasjoner i 13 industrisponsede studier med i alt 780 pasienter. Mens den angitte komplikasjonsraten var o \% i de publiserte originalstudiene, fant de ved gjennomgang av dokumenter fra FDA (United States Food and Drug Administration) en rate på 10-50 \%. Komplikasjoner som kan oppstå ved bruk av rhBMP-2, er løsning av implantat, infeksjon, urogenitale komplikasjoner og retrograd 
ejakulasjon ved fremre avstivningsoperasjoner i lenderyggen; radikulitt, ektopisk beindanning, beinresorpsjon og dårligere global effekt ved bakre avstivningsoperasjoner i lenderyggen; og i tillegg luftveisobstruksjon ved avstivningsoperasjoner i nakken.

BMP ble oppdaget i 1965 og videre forskning ledet til preparatet rhBMP-2 for bruk i klinisk praksis. Dette er et protein utviklet ved rekombinant teknikk og som ved infusjon i små doser kan stimulere pasientens beinvekst. Det vil gjøre det unødvendig å utføre en tilleggsoperasjon for å høste bein fra for eksempel hoftekammen for rekonstruksjon ved avanserte ryggoperasjoner eller ved manglende tilheling av brudd. I dag brukes det vanligvis bein fra ryggen ved avstivningsoperasjoner med eller uten instrumentering i Norge, og rhBMP-2 brukes når vanlige prosedyrer anses som utilstrekkelige. Forventningene til rhBMP-2 var store etter at den første randomiserte studien fikk Volvoprisen for beste kliniske ryggstudie i 2002 (므). På hjemmesiden til New York-sykehuset Hospital for Special Surgery ble det nye preparatet i 2002 beskrevet i et notat med tittelen «rhBMP-2 Revolutionizes Spinal Fusion» (3).

\section{Alvorlige komplikasjoner underrapportert}

Allerede i en oversiktsartikkel fra 2002 ble det imidlertid advart mot komplikasjoner (4.). De eksakte årsakene til komplikasjoner er vanskelig å fastslå fordi rhBMP-2 er involvert i en rekke fysiologiske og patologiske mekanismer, bl.a. inflammasjon, beninduksjon og resorpsjon, signalsystemer for vekst, malignitet og endret immunrespons. Når medikamentet er involvert i så mange prosesser, er det påfallende at komplikasjoner ikke ble funnet ved klinisk bruk i noen av de 13 originalartiklene (1). I 2008 ble en rapport om livstruende komplikasjoner offentliggjort (5). Den omhandlet tidlig postoperative svelge-, puste- og snakkevansker ved operasjoner i nakken, komplikasjoner som nødvendiggjorde intubering, antiinflammatorisk medisin, og ev. trakeotomi eller reoperasjon. Rapporten førte til mer kritisk oppmerksomhet om klinisk bruk av rhBMP-2. En studie som omhandlet bruk av rhBMP-2, ble trukket fra den britiske utgaven av det velrennomerte tidsskriftet Journal of Bone and Joint Surgery pga. misligheter ved gjennomføring av studien og mulig manglende rapportering av finansielle transaksjoner (므). Men det var fortsatt sterk tiltro til preparatet. Så sent som i juli 2010 anbefalte et panel i FDA bruken av rhBMP-2 og karakteriserte metoden som et monumentalt fremskritt i det arsenal av alternativer for beintransplantat man hadde tilgjengelig for avstivningsoperasjoner i ryggen (7.).

Bruken av rhBMP-2 akselererte fra o,7\% i 2002 til $25 \%$ av 420 ooo avstivningsoperasjoner i USA i 2006 ( $\underline{8})$. Bruken er verdensomspennende, og preparatet rh-BMP-2 eller Infuse brukes også i Norge, men omfanget er ukjent. Det har vært antydet at produsenten kan ha tjent så mye som 1 milliard amerikanske dollar ved salg av Infuse siste år. Forfatterne av den systematiske oversiktsartikkelen dokumenterer at nesten alle forfatterne av de industrisponsede artiklene hadde finansielle bindinger. I studier som inkluderte 20-100 pasienter, foregikk det transaksjoner på 1 million dollar til én eller flere forskere, mens det i studier som omfattet mer enn 100 pasienter, er dokumentert finansielle transaksjoner på mer enn 10 millioner dollar. Funnene i den systematiske oversiktsartikkelen gir dermed sterk mistanke om underrapportering av komplikasjoner for å oppnå økt fortjeneste. Forskningen har ført til at pasienter er blitt utsatt for betydelig risiko uten å ha fătt en klar gevinst av behandlingen (9).

\section{Manglende rapportering av interessekonflikter}

Forskere har et betydelig ansvar for at studier rapporteres etter gjeldende regler, og at alle interessekonflikter er transparente. Dette er særlig viktig når resultatene er oppsiktsvekkende, slik som i de originale publikasjonene av rhBMP-2. Alle de 13 studiene er finansiert av produsenten av Infuse. Studiene utgår fra flere forskergrupper og har åtte 
forskjellige førsteforfattere. Carragee konkluderer med at interessekonflikter ikke er tilstrekkelig rapportert i noen av studiene (1). Dette gjelder både om det foreligger interessekonflikt og størrelsen på de økonomiske transaksjonene. Forfatteren av den første randomiserte studien om rhBMP-2 var samme år som studien ble publisert, i egenskap av assisterende redaktør i Spine, med på å undertegne en lederartikkel om interessekonflikter (10). Lederartikkelen har undertittelen «Breaking down the barriers to restore public confidence: disclosure».

Det er grunn til å reise spørsmål om fagfellevurderernes uavhengighet. Kanskje hadde både fagfellevurdererne og tidsskriftredaktørene for stor respekt for de kjente forskerne som sto bak originalstudiene? Det er heller ikke mulig å utelukke at noen av forfatterne av originalstudiene har hatt ulike roller med mulighet til å velge de fagfellevurdererne som de ønsket.

\section{Behov for $\emptyset$ kt offentlig finansiering av forskning}

Et samarbeid mellom industrien og den medisinske forskning er nødvendig. Det er mange eksempler på at nye behandlingsmetoder er utviklet i samarbeid med industrien. Etter min mening bør forskere fortsatt kunne motta honorar fra industrien for å holde forelesninger, reisestøtte til internasjonale konferanser og støtte til gjennomføring av studier, men slike forhold må være transparente og tilstrekkelig detaljerte. Troverdigheten til medisinsk forskning og til den ortopediske industrien er imidlertid betydelig svekket etter publisering av den systematiske oversiktsartikkelen. Selv om det alltid vil være interesse for ny teknologi, må pasienten være første prioritet og legen eller kirurgen må ikke glemme primum non nocere, først gjør ingen skade. Det skulle være unødvendig å minne om dette, men mangel på rapportering av komplikasjoner i de 13 industrisponsede studiene har medført mange skader og reiser spørsmål om nye behandlingsmetoder bør godkjennes for klinisk bruk før de er utprøvd i studier ledet av helt uavhengige forskere (1ㅡ).

Den amerikanske skandalen vil etter min mening tvinge frem økt offentlig finansiering av medisinsk forskning. Det kan ikke utelukkes at dette i sin tur kan redusere utgifter til behandlingsmetoder som har mer skade enn virkning. Er det mulig å hindre at en liknende skandale skal oppstå i fremtiden eller er det mer sannsynlig å spørre: Hva blir det neste?

Randomiserte studier representerer en gullstandard og danner grunnlaget for kunnskapsbasert medisin. Derfor er det viktig at data som inngår i slike studier, kan kvalitetssikres før publisering. Registerdata kan her være et nyttig hjelpemiddel. I Norge har vi et nasjonalt ryggregister som bl.a. gir mulighet for at pasienten og ryggkirurgen registrerer komplikasjoner uavhengig av hverandre.

\section{LITTERATUR}

1. Carragee EJ, Hurwitz EL, Weiner BK. A critical review of recombinant human bone morphogenetic protein-2 trials in spinal surgery: emerging safety concerns and lessons learned. Spine Journal 2011; 11: 471-91.

2. Boden SD, Kang J, Sandhu H et al. Use of recombinant human bone morphogenetic protein-2 to achieve posterolateral lumbar spine fusion in humans: a prospective, randomized clinical pilot trial: 2002 Volvo Award in clinical studies. Spine (Phila Pa 1976 ) 2002; 27: 2662-73.

3. Hospital for Special Surgery. www.hss.edu/newsroom_1139.asp. (11.10.2011).

4. Poynton AR, Lane JM. Safety profile for the clinical use of bone morphogenetic proteins in the spine. Spine 2002; 27 (suppl): 40-48.

5. Center for Devices and Radiological Health Notifications (Medical Devices) - FDA. Public Health Notification: life-thretening complications associated with recombinant human bone morpogenic protein in cervical spine fusion.

wwwfdagov/MedicalDevices/Safety/AlertandNotices/PublicHealthNootifications/ucmo620oo htm (11.10.2011). 
6. Kuklo TR, Groth AT, Anderson RC et al. Recombinant human bone morphogenetic protein-2 for grade III open segmental tibial fractures from combat injuries in Iraq. J Bone Joint Surg (Br) 2008; 9oB: $1068-72$.

7. Medtronics report. www.news-medical.net/news/20100728/Medtronic-reports-FDA-Panelsaffirmative-votes-on-AMPLIFY-rhBMP-2-Matrix-for-posterolateral-spine-fusion.aspx. (11.10.2011).

8. Cahill KS, Chi JH, Day A et al. Prevalence, complications, and hospital charges associated with use of bone-morphogenetic proteins in spinal fusion procedures. JAMA2009;302: 58-66.

9. Mirza SK. Folly of FDA-approval studies for bone morphogenetic protein. Spine Journal 2011; 11: $495^{-9}$.

10. Weinstein JN, Nachemson A, Kaneda K et al. Breaking down the barriers to restore public confidence: disclosure. Spine 2002; 27: 6-8.

11. Spengler DM. Resetting standards for sponsored research: do conflicts influence results? Spine Journal 2011; 11: $492-4$.

Publisert: 15. november 2011. Tidsskr Nor Legeforen. DOI:10.4045/tidsskr.11.0841

Mottatt 1.8. 2011, første revisjon innsendt 18.8. 2011, godkjent 8.9. 2011. Medisinsk redaktør Anne Kveim Lie.

(C) Tidsskrift for Den norske legeforening 2023. Lastet ned fra tidsskriftet.no 26. april 2023. 